\title{
Lonicera iberica M. Bieb.: Investigation Antioxidant Activity and Bioactive Chemicals
}

\author{
Fatma Ergün ${ }^{1, a, *}$ \\ ${ }^{1}$ Kırşehir Ahi Evran University 40100 Kırşehir, Turkey \\ *Corresponding author

A R T I C L E I N F O A B S T R A C T \\ Research Article \\ In this study, it was investigated the total amounts of phenolic and flavonoid substances and \\ antioxidant activities in different solvent extracts of Lonicera iberica M. Bieb. wild fruit. Total \\ phenolic contents of the extracts were determined as equivalent to gallic acid using Folin-Ciocalteu \\ reagent, and total flavonoid contents as equivalent to quercetin by aluminium nitrate method. In \\ Received : 12/04/2021 \\ Accepted : 04/05/2021 \\ addition, the antioxidant properties of the extracts were determined using free radical scavenging \\ (DPPH) and reducing power (FRAP) methods. The amount of total phenolic substance of L. iberica \\ fruits in hexane and methanol extracts was calculated as $30.96 \pm 0.67 \mathrm{mg}$ of GAE / $\mathrm{g}$ and $23.70 \pm$ \\ $1.56 \mathrm{mg}$ of GAE / $\mathrm{g}$, respectively. In addition, the amount of total flavonoid substance was \\ calculated as $46.50 \pm 8.54 \mathrm{mg}$ of $\mathrm{QE} / \mathrm{g}$ and $42.09 \pm 2.58 \mathrm{mg}$ of QE / g, respectively. It was \\ determined that DPPH radical scavenging activity correlated with total phenolic and flavonoid \\ Keywords: \\ Lonicera iberica \\ DPPH \\ amount of substance, and L. iberica had a strong antioxidant effect. It is predicted that our study \\ will shed light on new researches, since it is the first study done with L. Iberica fruits in this field.
}

FRAP

Phenolic substance

Flavonoid substance

\section{Introduction}

Forests are among the most important elements of nature. In addition, they are natural areas where many living things keep living vital activities. In terms of health, forests have a beneficial effect on many health problems such as hypertension, stress, depression and anxiety (Jarmer et al., 2021). Forests are rich environments that contain macro and micronutrients that are important for human nutrition, depending on the plant diversity (Rowland et al., 2017). Edible wild plants in forests are classified as vegetables, greens, fruits and grains, seeds and nuts (Abbasi et al., 2013; Sevindik et al., 2017; Mohammed et al., 2018). In addition to their nutritional value, these plants also have medicinal values (Turner et al., 2011; Mohammed et al., 2020). Recently, the increasing interest in natural nutrition has increased the tendency to these edible plants and has led to the formation of a new sector accordingly (Mahapatra and Panda, 2012).

Honeysuckle, which is a forest plant, is a shrub species belonging to the Caprifoliaceae family. In general, parts of edible honeysuckle as fruit, flower, branch, leaf and shell have been used in folk medicine for many years in many countries. Especially due to its antiseptic properties, its leaves are used in the treatment of stomach, throat and eye, while its branches are used as diuretic and its fruits as a general strengthener (Tunde et al., 2012). Plekhanova (2000) reported that flowers of honeysuckle species are rich in ascorbic acid, contain bioactive flavonoids, and plants and fruits are highly resistant to cold. There are many types of honeysuckle. The fruits of Lonicera caerulea L. (blue honeysuckle), one of these species, are rich in phenolic compounds and is a widely used herbal medicine as an antiinflammatory (Sandigawad, 2015). Lonicera japonica Thunb. is another type of honeysuckle reported to have antimicrobial, antioxidative, antiviral and antiinflammatory effects (Shang, 2011).

L. iberica (Dadaş honeysuckle, lili, lilik), is another species of honeysuckle that grow in $800-2500 \mathrm{~m}$ in Turkey, Caucasia and in Northern Iran (Eminağaoğlu et al., 2014). In Turkey, it spreads over a wide area in North East Anatolia, especially in Artvin, Erzurum and Kars. The stem part of the 
plant is used in making music instrument sticks, and the fibrous parts are used in making bath fiber. L. iberica, which is among the edible forest fruits, has a berry-like, red, compound and very small seeded fruit. In this species, flowering occurs in June-July and reaches fruit maturity in October (Eminağaoğlu et al., 2014). This type is called "lilik" among people in Eastern Anatolia. It is among the indispensable fruits of the shepherds and hunters living in the region. Fruits are sweet but leave a slightly bitter taste in the mouth after eating (figure 1).

The species belonging to the Caprifoliaceae family, which grow spontaneously without any intervention in nature, have been the subject of many studies. However, there is no study on L. iberica specie. In this study, the total phenolic content of $L$. iberica fruit was determined equivalent to gallic acid by using Folin-Ciocalteu reagent. Total flavonoid content was calculated as equivalent to quercetin by aluminum nitrate method. In addition, antioxidant capacity was determined using DPPH and FRAP methods. By comparing the results of the study with other species and forest fruits in the literature, it was contributed to the emergence of the bioactive power of $L$. iberica.

\section{Materials and Methods}

\section{Supply of Plant Samples}

The samples to be used in this study were collected from plants (L. iberica) spontaneously grown in their natural environment at coordinates of $40^{\circ} 49^{\prime} 36$ "N $42^{\circ} 05^{\prime} 47^{\prime \prime} \mathrm{E}$ $(1521 \mathrm{~m})$. The collected samples were washed first with tap water and then with distilled water in order to be purified from physical contamination. L. Iberica fruits were dried in the shade and stored at $+4^{\circ} \mathrm{C}$ until use.

\section{Preparation of L. Iberica Fruit Extracts}

Methanol and hexane extraction of $L$. iberica fruit was carried out according to literature (Gulcin et al., 2005). $15 \mathrm{~g}$ of dried plant specimens was ground in a grinder and placed in a 1 liter closed flask. Then solvent $(300 \mathrm{~mL})$ twenty times the amount of the sample was added and stirred in the magnetic stirrer. The extracts obtained was filtered. This procedure was repeated three times at regular intervals. The filtered extracts were combined. These procedures were done separately for hexane and methanol. Methanol was removed at $45^{\circ} \mathrm{C}$ and hexane $40^{\circ} \mathrm{C}$ in the evaporator. The extracts were stored at $+4^{\circ} \mathrm{C}$ for the studies.

\section{Determination of Total Phenolic Substances}

Determination of total phenolic substance in extracts obtained from L.iberica fruit was made according to FolinCiocaltaeu method (Slinkard and Singleton, 1977). Gallic acid was used as standard and standard graphic was prepared. Solutions of plant methanol and hexane extracts at a concentration of $1000 \mathrm{ppm}$ were prepared. $50 \mu \mathrm{L}$ was taken from stock solutions, completed to $1840 \mu \mathrm{L}$ with distilled water. $40 \mu \mathrm{L}$ of Folin-Ciocalteu reagent (FCR) was added to the mixture and incubated for 3 minutes at room temperature. Then, $120 \mu \mathrm{L}$ of $2 \%$ (w / v) $\mathrm{Na}_{2} \mathrm{CO}_{3}$ solution was added. The mixture was kept in room temperature for 2 hours. The absorbance of the samples was measured against a blank at $760 \mathrm{~nm}$. Three parallel studies were performed for measurements. The total phenolic contents of the extracts were found as equivalent to gallic acid by using the equation obtained from the standard graph (mg GAE /g).

\section{Determination of Total Flavonoid Substance}

The total flavonoid contents of the extracts prepared were determined by aluminum nitrate method as equivalent to quercetin (Moreno et al., 2000). Quercetin was used as standard and standard graphic was prepared. $1000 \mathrm{ppm}$ solution was prepared from methanol and hexane extracts obtained from $L$. iberica fruit. $50 \mu \mathrm{L}$ of this stock solution was taken and the volumes were completed to $1920 \mu \mathrm{L}$ with methanol. $40 \mu \mathrm{L}$ of $1 \mathrm{M}$ potassium acetate was added and after one minute $40 \mu \mathrm{L}$ of $10 \%$ aluminum nitrate was added. It was incubated for 40 minutes. Absorbance at $415 \mathrm{~nm}$ against a blank prepared with pure water was measured. Three parallel studies were performed for measurements. The total flavonoid contents of the extracts were found as equivalent to quercetin using the equation obtained from the standard graph (mg QE /g).

\section{Determination of DPPH• Free Radical Scavenging Activity}

Free radical scavenging 1 activities of the extracts were found by using Blois method (Blois, 1958). 1,1-Diphenyl-2picrylhydrazyl (DPPH•) solution was used as free radical. 1000 ppm stock solution was prepared from hexane and methanol extracts of L. iberica fruit and 2,6-di-t-butyl-1hydroxytoluene (BHT) which was used as standard. 20, 40, 80 ve $100 \mu \mathrm{L}$ were taken from these stock solutions and their volumes were completed to $400 \mu \mathrm{L}$ with methanol. Then, $1600 \mu \mathrm{L} \mathrm{DPPH} \bullet$ solution $(0,1 \mathrm{mM})$ was added. The prepared solutions were incubated for 30 minutes at room temperature in the dark. The absorbance changes at $517 \mathrm{~nm}$ were measured against methanol. Control solution was prepared under the same conditions using methanol instead of sample and standard material. Decreasing absorbances yielded the amount of free $\mathrm{DPPH} \bullet$ solution remaining, i.e., radical scavenging activity.

$\% \mathrm{DPPH} \bullet$ radical scavenging activity was calculated by the following formula:

$$
\% \mathrm{DPPH} \bullet=\left[\left(\mathrm{A}_{0}-\mathrm{A}_{1}\right) / \mathrm{A}_{0}\right] \times 100
$$

$\mathrm{A}_{0}$ : Absorbance of control reaction

$\mathrm{A}_{1}$ : Absorbance of fruit extracts and standard solutions

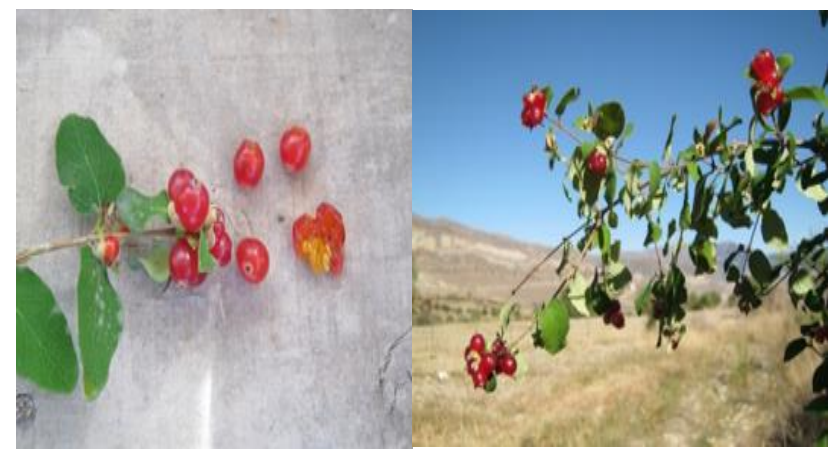

Figure 1. Lonicera iberica fruits. 


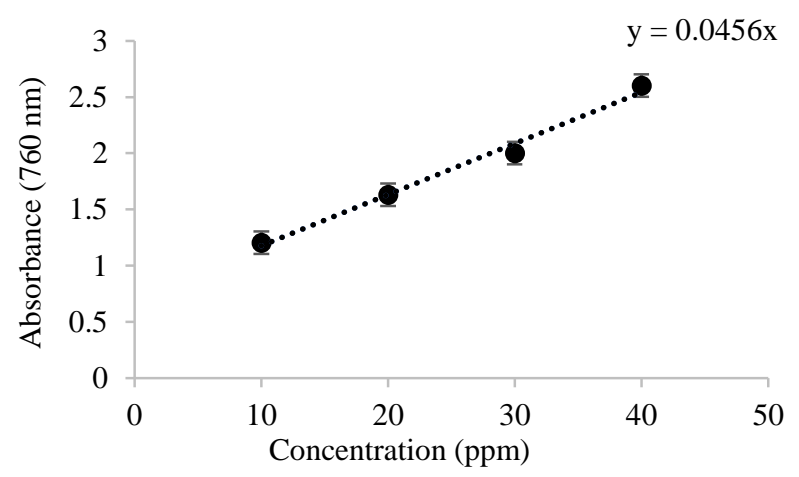

Figure 2. Calibration curve graph of gallic acid

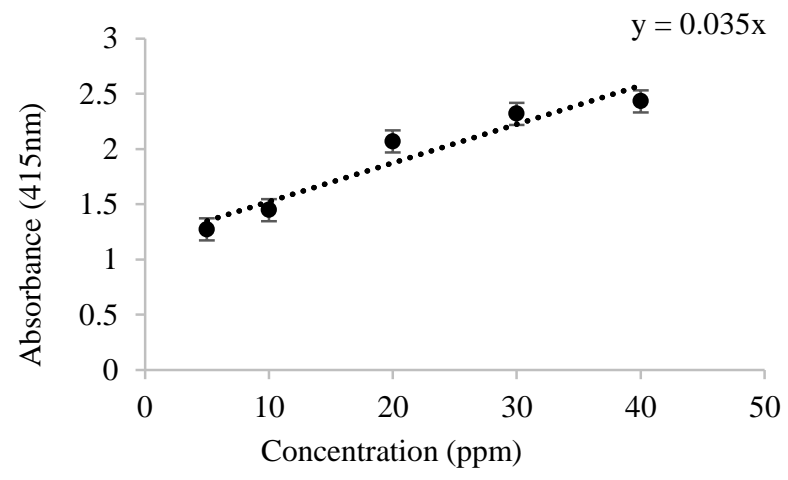

Figure 3. Calibration curve graph of quercetin

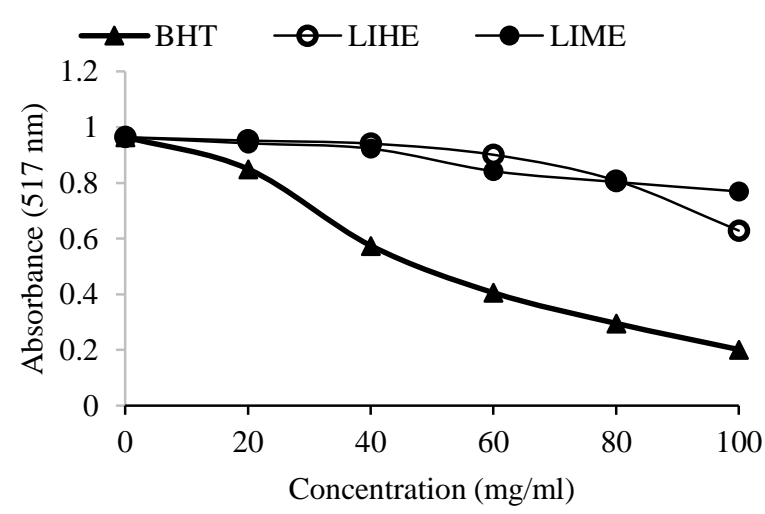

Figure 4. The DPPH• scavenging effect of hexane and methanol extracts and BHT at different concentrations (BHT: Butylated hydroxytoluene, LIHE: L. iberica hexane extracts, LIME: L.iberica methanol extracts).

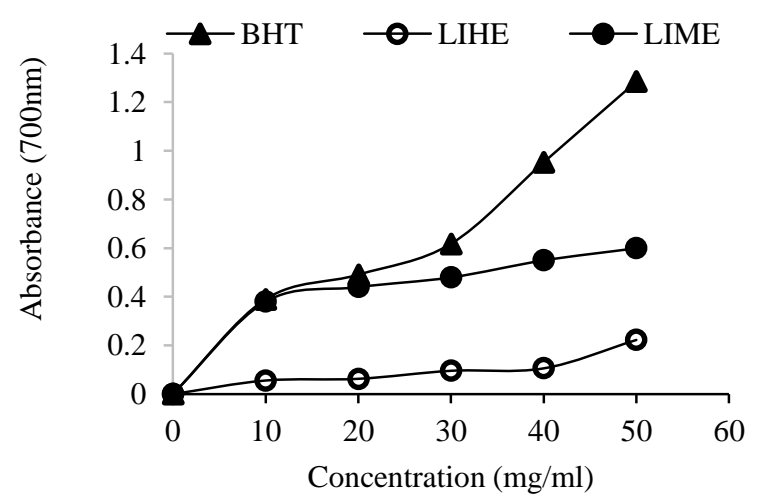

Figure 5. Comparison of $\mathrm{Fe}^{3+}-\mathrm{Fe}^{2+}$ reducing power activities of extracts of $L$. iberica fruits with BHT $(20-50 \mathrm{mg} / \mathrm{mL})$

(BHT: Butylated hydroxytoluene, LIHE: L. iberica hexane extracts, LIME: L. iberica methanol extracts)

\section{Determination of Ferric Reducing Power (FRAP)}

The determination of $\mathrm{Fe}^{3+}$ reducing power was made according to Oyaizu (1986). 1000 ppm stock solution was prepared from hexane and methanol extracts. These stock solutions were taken into the tube at that the concentration was $10,20,30,40$ and $50 \mathrm{mg} / \mathrm{mL}$ ). Distilled water was added so that the total volume was $1.0 \mathrm{~mL} .2 .5 \mathrm{~mL}$ of phosphate buffer (0.2 $\mathrm{M} \mathrm{pH} \mathrm{6.6)} \mathrm{and} \mathrm{potassium} \mathrm{ferricyanide}$ (1\%) solution were added to these solutions and kept in a water bath at $50^{\circ} \mathrm{C}$ for 20 minutes. Then $2.5 \mathrm{~mL}$ of $10 \%$ trichloroacetic acid (TCA) was added and vortexed. $2.5 \mathrm{~mL}$ ultrapure water and $0.5 \mathrm{~mL}$ iron (III) chloride $(0.1 \%)$ were added to $2.5 \mathrm{~mL}$ samples taken from vortexed tubes and the absorbance at $700 \mathrm{~nm}$ measured against a blank. BHT was used as standard and the same process was applied to the prepared standard solution of $1000 \mathrm{ppm}$.

\section{Result and Discussion}

Plants, which grow spontaneously without human intervention and called wild fruits, have been the subject of many studies because they are eaten by humans and animals. Wild fruits are important in terms of the nutrients they contain, especially antioxidants. Recently, due to the increasing interest in natural nutrition, the trend towards edible wild fruits, which are seen as a source of bioactive components, has increased (Mohammed et al., 2021).

In this study, total phenolic and flavanoid content, $\mathrm{DPPH} \bullet$ radical scavenging activities and $\mathrm{Fe}^{3+}$ reducing power capacity were determined in extracts of $L$. iberica fruit that grown in North Anatolia Turkey. The activity results obtained were compared with standard.

The yields of hexane and methanol extracts of $L$. iberica fruits were calculated as $26.01 \%$ and $46.06 \%$, respectively, and are shown in table 1 . Folin-Ciocaltaeu method was used to determine the amount of phenolic substance. Total amount of phenolic substance was calculated as equivalent to gallic acid by using gallic acid standard graph given in figure 2.

It was determined that there is relatively more phenolic substance in hexane extracts of $L$. iberica fruits compared to methanol extracts. Total phenolic matter was calculated as $30.96 \pm 0.67 \mathrm{mg} \mathrm{GAE} / \mathrm{g}$ in hexane extracts and $23.70 \pm$ $1.56 \mathrm{mg} \mathrm{GAE} / \mathrm{g}$ in methanol extracts (Table 1.)

The values found are similar to the total phenolic substance amounts found by Dung et al., (2010) in ethanol extracts of $L$. japonica's dried flowers, leaves and branches. In another study, the total amount of phenolic substance of L. japonica was determined as $27.36 \pm 0.29 \mathrm{mg} \mathrm{GAE} / \mathrm{g}$ in the flowers and $7.81 \pm 0.39 \mathrm{mg} \mathrm{GAE} / \mathrm{g}$ in the stem ( $\mathrm{Li}$ et al., 2008). While the values we found in the hexane and methanol extracts of $L$. iberica are close to the values determined in the flowers of $L$. japonica, they are higher than the value found in the stem extracts of L. japonica. In addition, the values we found are lower than the total amount of phenolic substances found in L. caerulea (Polikova et al., 2008).

The total amount of flavonoids in our study was calculated as equivalent to quercetin using the standard graph of quercetin. The standard graphic is given in Figure 3 . The total amount of flavonoid was determined as 46.50 $\pm 8.54 \mathrm{mg} \mathrm{QE} / \mathrm{g}$ in the hexane extract and $42.09 \pm 2.58 \mathrm{mg}$ $\mathrm{QE} / \mathrm{g}$ in the methanol extract. 
Table 1. Total phenolic and flavonoid substance amount and yield of $L$. iberica fruit extracts.

\begin{tabular}{l|ccc}
\hline \multicolumn{1}{c|}{ Exstract } & Yield (\%) & Total phenolics (mg of GAE/g) & Total flavonoids (mg of QE/g) \\
\hline L.iberica hexane extract & 26.01 & $30.96 \pm 0,67$ & $46.50 \pm 8.54$ \\
L.iberica methanol extract & 46.06 & $23.70 \pm 1,56$ & $42.09 \pm 2,58$ \\
\hline
\end{tabular}

Table 3. DPPH॰\% radical scavenging activities of $L$. iberica fruit extracts and BHT (BHT: Butylated hydroxytoluene, LIHE: L. iberica hexane extracts, LIME: L. iberica methanol extracts)

\begin{tabular}{l|ccccc}
\hline \multicolumn{1}{c|}{ Extracts / standard } & $20 \mathrm{mg} / \mathrm{mL}$ & $40 \mathrm{mg} / \mathrm{mL}$ & $60 \mathrm{mg} / \mathrm{mL}$ & $80 \mathrm{mg} / \mathrm{mL}$ & $100 \mathrm{mg} / \mathrm{L}$ \\
\hline LIHE & 1.2 & 2.3 & 6.5 & 16 & 34.8 \\
LIME & 2.2 & 4.2 & 12.6 & 16.7 & 20.22 \\
BHT & 15.04 & 41.49 & 56.95 & 69.91 & 77.69 \\
\hline
\end{tabular}

Table 4. L. iberica extracts and of BHT IC 50 values (BHT: Butylated hydroxytoluene, LIHE: L. iberica hexane extracts, LIME: L. iberica methanol extracts)

\begin{tabular}{l|c}
\hline \multicolumn{1}{c|}{ Extracts and standard } & $\mathrm{IC}_{50}(\mathrm{mg} / \mathrm{mL})$ \\
\hline LIHE & 155.54 \\
LIME & 192,09 \\
BHT & 57,20 \\
\hline
\end{tabular}

When the total phenolic substance amounts we determined in L. iberica fruit extracts (Table 1) were compared with similar wild fruit studies; it is seen that they are similar to Vibirnum opulus L. (Demirkol et al., 2018), Indian gooseberry (Rahman et al., 2016) and Punica granatum (Abdolahi, 2018), and higher than Lycium barbarum L. (Engin, 2019). In addition, the total amount of flavonoids found in the study is higher than the values determined in the study conducted on edible wild fruits (Hippophae rhamnoides L., Crataegus monogyna Jacq., Rubus fruticosus L. Cornus mas L., Prunus spinosa L., Rosa canina L., Prunus padus L.) (Cosmulescu et al., 2017; Pehlivan et al., 2018).

$\mathrm{DPPH} \bullet$ free radical was used to determine the antioxidant activity of $L$. iberica fruit extracts. Phenolic compounds in plants give a hydrogen atom to the DPPH radical, forming $\mathrm{DPPH}_{2}$. Thus, they prevent the negative effects of free radicals.DPPH $\bullet$ method for determining free radical scavenging activity is used to determine radical scavenging activities, especially in plant extracts.In this study, the absorbance decrease of DPPH• radical at $517 \mathrm{~nm}$ was measured, and the amount of free DPPH• solution remaining, i.e., free radical scavenging activity, was determined.BHT was used as a standard in activity studies.Parallel to the increase in the concentration of hexane and methanol extracts $(20-100 \mu \mathrm{g} / \mathrm{mL})$, an increase in $\mathrm{DPPH} \cdot$ radical scavenging activities was observed (figure 4).

$\mathrm{DPPH} \bullet$ radical scavenging activities of the extracts and BHT were calculated (Table 3). In the antioxidant analysis, when the DPPH $\bullet$ radical scavenging activities were compared at $100 \mu \mathrm{g} / \mathrm{mL}$ concentration, it was observed that although the activity of hexane extracts was lower than the standard used, it was higher than the methanol extracts. Jahromi et al. found DPPH $\bullet$ radical scavenging activity at $100 \mathrm{mg} / \mathrm{mL}$ in the ethanol extract of Lonicera nummularifolia as $12.28 \% \pm 1.34$ (Jahromi, 2020). It is seen that this value is lower than the values we found.

The concentration of extract and standard substance that provides inhibition of $50 \%$ of DPPH radical scavenging was determined as IC50. This value was calculated using graph of DPPH• \% radical scavenging activity values versus studied concentrations
There is an inverse proportion between the $\mathrm{IC}_{50}$ value and the DPPH radical scavenging activity. Accordingly, the activity ranking is BHT> LIHE> LIME. It was determined that methanol and hexane extracts could not decrease below $50 \%$ inhibition value. It is seen that the hexane extract can achieve $50 \%$ inhibition at a concentration of $155.54 \mathrm{mg} / \mathrm{mL}$, and the methanol extract at a concentration of $192.09 \mathrm{mg} / \mathrm{mL}$. Dung et al., in their study with $L$. japonica in 2010 , found the best result in flowers as $19.45 \pm 2.74 \mathrm{mg} / \mathrm{mL}$. In another study, DPPH• radical scavenging activity in $L$. japonica was determined as $204.26 \pm 1.79 \mathrm{mmol} / \mathrm{g}$ (Zhenga et al., 2018). In a study conducted on five different Lonicera flowers, $\mathrm{IC}_{50}$ values were found to range between $235.27 \pm 1.21 \mathrm{mg} / \mathrm{mL}-905.23$ $\pm 1.02 \mathrm{mg} / \mathrm{mL}$ (Zhou et al., 2020). When the DPPH• radical scavenging activity results found in L. iberica fruits are examined, although there was a difference between the species, it was determined that it showed high activity.

$\mathrm{Fe}^{3+}-\mathrm{Fe}^{2+}$ reduction capacity of L.iberica fruit extracts and BHT was determined by FRAP method. The antioxidant effect of reducing agents in plants is based on the principle of giving a hydrogen atom and breaking the radical chain. In $\mathrm{Fe}^{3+}-\mathrm{Fe}^{2+}$ reduction capacity measurements, absorbances at $700 \mathrm{~nm}$ were determined and the graph was obtained by placing the absorbance values against the concentration (Figure 5).

In this graph, increasing absorbance values indicate the reducing power capacity. Reducing power increased in response to increasing concentration in $L$. iberica hexane and methanol extract. With increasing concentration in methanol extracts, the increase in reducing power was much greater. The reducing power activity ranking is BHT > LIME> LIHE. At a concentration of $50 \mathrm{mg} / \mathrm{mL}$ reducing power capacity of methanol extract reached the value in $30 \mathrm{mg} / \mathrm{mL}$ of BHT, a synthetic antioxidant.

\section{Conclusion}

The results of this study show that $L$. iberica fruits have DPPH radical scavenging and reducing power activity, and can be used as a natural antioxidant source and alternative food supplement. However, due to the lack of previous 
research on L. iberica, more studies are needed to identify its antioxidant components.

\section{Acknowledgemens}

The author is thankful to Mr. Demirel ERGÜN for help and to Mr. Ergin ERGÜN for the photographs. This study was supported by the Kırşehir Ahi Evran University Scientific Research Projects Coordination Unit. Project Number: SYO.A4.20.002

\section{Conflicts of Interest}

The authors declare that they have no conflict of interest.

\section{References}

Abbasi AM, Khan MA, Khan N, Shah MH. 2013. Ethnobotanical survey of medicinally important wild edible fruits species used by tribal communities of Lesser Himalayas-Pakistan. Journal of Ethnopharmacology, 148(2): 528-536.

Abdolahi N, Soltani A, Mirzaali A, Soltani S, Balakheyli H, Aghaei M. 2018. Antibacterial and antioxidant activities and phytochemical properties of Punica granatum flowers in Iran. Iranian Journal of Science and Technology, Transactions A: Science, 42: 1105-1110.

Blois MS. 1958. Antioxidant determinations by the use of a stable free radical. Nature, 181: 1199-1200.

Cosmulescu S, Trandafir I, Nour V. 2017. Phenolic acids and flavonoids profiles of extracts from edible wild fruits and their antioxidant properties. Int. J. Food Prop., 20: 3124-3134.

Demirkol ÖŞ, Yakan Aİ, Alifakı YÖ. 2018. Gilaburu (Vibirnum opulus L.) meyvesinden fenolik bileşiklerin ultrason destekli ekstraksiyonu, The journal of Food, GIDA 43(5): 846-855.

Dung NT, Bajpai VK, Rahman A, Yoon JI, Kang SC. 2011. Phenolic contents, antioxidant and tyrosinase inhibitory activities of Lonicera japonica Thunb. Journal of Food Biochemistry, 35(1): 148-160.

Eminağaoğlu Ö, Yüksel E, Aksu G. 2014. Türkiye'nin Doğal Egzotik Ağaç ve Çalıları I, Orman Genel Müdürlüğü Yayınlar1 422-431.

Engin MS, Kalkan S, Otağ MR. 2019. Goji berry (Lycium barbarum L.) Meyvesinin farklı çözgenlerden elde edilen ekstratlarının toplam fenolik içerikleri ile antioksidan ve antimikrobiyal aktivitelerinin karşılaştırılması. Journal of Anatolian Environmental and Animal Sciences, 4(3): 359-365.

Gulcin I, Berashvili D, Gepdiremen A. 2005. Antiradical and antioxidant activity of total anthocyanins from Perilla pankinensis decne. Journal of Ethnopharmacology, 101: 287 293.

Jahromi MAF, Emami A, Nazeri R, Pirbonyeh N. 2020. Antibacterial and Antioxidant Activity of extract and fractions of Lonicera nummularifolia Jaub and Spach. Trends in Pharmaceutical Sciences, 6(2): 131-142.

Jarmer MS, Throner V, Kirschneck M, Immich, G, Frisch D, Schuh A. 2021. The Psychological and Physical Effects of Forests on Human Health: A Systematic Review of Systematic Reviews and Meta Analyses. Int. J. Environ. Res. Public Health, 18: 1770.

Jurikova T, Rop O, Mlcek J, Sochor J, Balla S, Szekeres L, Hegedusova A, Hubalek J, Adam_V, Kizek R. 2012. Phenolic Profile of Edible Honeysuckle Berries (Genus Lonicera) and Their Biological Effects. Molecules, 17(1): 61-79.

Li HB, Wong CC, Cheng KW, Chen F. 2008. Antioxidant properties in vitro and total phenolic contents in methanol extracts from medicinal plants. LWT-Food Science and Technology, 41: 385-390.
Mahapatra AK, Panda PC. 2012. Wild edible fruit diversity and its significance in the livelihood of indigenous tribals: Evidence from eastern India. Food Security, 4(2): 219-234.

Mohammed FS, Şabik AE, Sevindik E, Pehlivan M, Sevindik M. 2020. Determination of Antioxidant and Oxidant Potentials of Thymbra spicata Collected from Duhok-Iraq. Turkish Journal of Agriculture-Food Science and Technology, 8(5): 1171-1173.

Mohammed FS, Akgul H, Sevindik M, Khaled BMT. 2018. Phenolic content and biological activities of Rhus coriaria var. zebaria. Fresenius Environmental Bulletin, 27(8): 5694-5702.

Mohammed FS, Pehlivan M, Sevindik E, Akgul H, Sevindik M, Bozgeyik I, Yumrutas O. 2021. Pharmacological properties of edible Asparagus acutifolius and Asparagus officinalis collected from North Iraq and Turkey (Hatay). Acta Alimentaria, 50(1): 136-143.

Moreno MIN, Isla MI, Sampietro AR, Vattueno MA. 2000. Comparison of the free radical scavenging activity of propolis from several regions of Argentina. Journal of Ethnopharmacology, 71: 109-114.

Oyaizu M. 1986. Study on products of Browning reactions: antioxidative activities of products of browning reaction prepared from glucosamine. Jpn. J. Nutr, 44: 307-315.

Palikova I, Heinrich J, Bednař P, Marhol P, Křen V, Cvak L, Valentova K, Růžička F, Hola V, Kolař M, Šimanek V, Ulrichova J. 2008. Constituents and antimicrobial properties of blue honeysuckle: a novel source for phenolic antioxidants. Journal of Agricultural and Food Chemistry, 56: 1188311889.

Pehlivan M, Mohammed FS, Sevindik M, Akgul H. 2018. Antioxidant and oxidant potential of Rosa canina. Eurasian Journal of Forest Science, 6(4): 22-25.

Plekhanova MN. 2000. Blue honeysuckle (Lonicera caerulea L.)A new commercial berry crop for temperate climate: Genetic resources and breeding. Acta Hortic., 538: 215-220.

Rahman MM, Khan FE, Das R, Hossain MA. 2016. Antioxidant activity and total phenolic content of some indigenous fruits of Bangladesh. International Food Research Journal, 23(6): 2399-2404.

Rowland D, Ickowitz A, Powell B, Nasi R, Sunderland T. 2017. Forest foods and healthy diets: quantifying the contributions. Environ Conserv, 44: 102-114.

Sandigawad AM. 2015. Traditional Applications and Phytochemical Investigations of Lonicera japonica Thunb. International Journal of Drug Development and Research, 7(3): 42-49.

Sevindik M, Akgul H, Pehlivan M, Selamoglu Z. 2017. Determination of therapeutic potential of Mentha longifolia ssp. longifolia. Fresen Environ Bull, 26(7): 4757-4763.

Shang X, Pan H, Miao X, Ding H. 2011. Lonicera japonica Thunb.: Ethnopharmacology, phytochemistry and pharmacology of an important traditional Chinese medicine. Journal of Ethnopharmacology, 138(1): 1-21.

Slinkard K, Singleton VL. 1977. Total phenol analyses: Automation and comparison with manual methods. American Journal of Enology and Viticulture, 28: 49-55.

Turner N, Luczaj L, Migliorini P, Pieroni A, Dreon AL, Sacchetti LE, Paoletti MG. 2011. Edible and tended wild plants, traditional ecological knowledge and agroecology. Crit Rev Plant Sci, 30 (1-2): 198-225.

Zhenga J, Yua X, Manindera M, Xua B. 2018. Total phenolics and antioxidants profiles of commonly consumed edible flowers in China. International Journal of Food Properties, 21(1): 1524-1540.

Zhou RR, Liu XH, Chen L, Huang JH, Liang XJ, Wan D, Zhang SH, Huang LQ. 2020. Comparison of the antioxidant activities and phenolic content of five Lonicera flowers by HPLC-DAD/MS-DPPH and chemometrics. International Journal of Analytical Chemistry vol. 2020, Article ID 2348903, 2020. 